\title{
COMPARATIVE STUDY ON THE UNDERSTANDING OF RESPONSIVENESS IN PRE-SERVICE PRESCHOOL TEACHERS IN THE COVID-19 EMERGENCY SITUATION (2018-2020)
}

\author{
Inese Jurgena \\ University of Latvia, Latvia \\ Dagnija Cēdere \\ University of Latvia, Latvia \\ Ingrīda Keviša \\ Latvian Academy of Culture, Latvia
}

\begin{abstract}
The global pandemic of Civid-19 has led to significant changes in the transformation of the system of education and teacher training. Regarding the training of prospective preschool teachers at the institutions of higher education, there is a growing need to develop multiple competencies so that a teacher can create an emotionally safe and supervised learning environment. Our study highlights the importance of the responsiveness of preschool teachers in providing supportive responses, responsibility, and guidance regulating children's emotions in the pedagogical activity. The aim of the study is to analyze and compare the perceptions of students, pre-service preschool teachers, on teachers' emotional responsiveness before the global pandemic and during the Covid-19 emergency. The materials and methods used in the study include the theoretical method - the analysis of literature - and the empirical method - a survey of 600 part-time students working in pre-school educational institutions in 2018 and in 2020. The survey was conducted online. The data were processed using the software SPSS. The results of the study demonstrate that, generally, the Covid-19 emergency has increased the willingness of prospective preschool teachers to undertake responsibility and leadership in regulating children's emotions. The students have become more responsible and determined; their understanding of the importance of emotional responsiveness in teacher's work is higher than before the pandemic.
\end{abstract}

Keywords: Covid-19 emergency situation, preschool teachers, responsiveness.

\section{Introduction}

Given the announcement of the World health Organization on March 11, 2020 that the spread of Covid-19 had reached pandemic proportions and the declaration of a state of emergency not only in Latvia and in Europe, but in the world, new demands have been set for the transformation of the system of 
Jurgena et al., 2021. Comparative Study on the Understanding of Responsiveness in Pre-Service Preschool Teachers in the Covid-19 Emergency Situation (2018-2020)

education and for teacher preparedness to work effectively under the conditions of the pandemic.

The pandemic has had a profound impact on the world's system of education and has led to restrictions and the closure of educational institutions. Overall, Covid-19 affects more than 1.5 billion learners of all ages (UNESCO, 2020; UNICEF, 2020).

To limit the spread of the Covid-19 virus, the Latvian government also declared the state of emergency, ordering to close all educational institutions, stop the face-to-face study process and to provide remote learning (Cabinet of Ministers of the Republic of Latvia, 2020).

The training of prospective preschool teachers at the institutions of higher education is especially complicated in the situation caused by the pandemic as it implies the need to develop a variety of competences in practice so that a teacher would be able to provide an emotionally safe and supervised learning environment, paying special attention to the specifics of the work of preschool teachers in developing children's skills at an early stage (OECD, 2019).

Therefore, high-quality training of preschool teachers in the conditions of Covid-19 emergency is very important, with a special focus on improving students' social and emotional skills and raising awareness of the importance of teacher's responsiveness in developing child's self-regulation and building positive, supportive relationships with children and parents.

The aim of the article is to analyze and compare the perceptions of part-time teacher-training students working at the institutions of preschool education on teachers' emotional responsiveness before the global pandemic and in the Covid19 emergency.

\section{Theoretical Basis of the Problem}

Several studies have identified unique features related to the implementation of teacher education, especially preschool teacher training programs, in the difficult situation caused by the pandemic of Covid-19. It is well known that the acquisition of practical experience, which develops teacher's professional identity (Donitsa-Schmidt, Smadar, \& Ramot, 2020; Velle, Newman, Montgomery, \& Hyatt, 2020), and the advancement of teacher's social and emotional competence in connection with the formation of teacher's emotional responsiveness (Hadar, Ergas, Alpert, \& Ariav, 2020; Ferreira, Martinsone, \& Talič, 2020; Lang, Jeon, Sproat, Brothers, \& Buttner, 2020) are very important aspects in the training of prospective teachers.

The need to switch to the mode of online learning raised the topicality of these issues; besides, students' anxiety and stress increased (Sangiter, Stoner, \& Flood, 2020). The exceptional circumstances of Covid-19 also highlighted the 
attractiveness of the teaching profession in the labor market (Donitsa-Schmidt et al., 2020).

So far, research on the specific nature of the work of preschool teachers has substantiated the findings that, in the process of learning, the teacher needs to provide an emotionally safe and supervised environment in which children's social and emotional learning takes place (Denham, Basett, \& Zinsser, 2012); consequently, social and emotional abilities, including teacher's responsiveness as a reaction to children's negative emotions, are very important in the pedagogical activity of preschool teachers (Buettner, Jeon, Hur, Rachel, \& Garcia, 2016; Lang, Mouzourou, Jeon, Buettner, \& Hur, 2017) because they have a significant impact on children's general and emotional development and lead to far-reaching consequences related to children's behavioral problems later in life (Fabes, Poulin, Eisenberg, \& Madden-Derdich, 2002 ). Inappropriate reaction of adults, including punishing the child and minimizing the significance of child's emotions, affects the development of children's emotional competence (Perlman, Camras, \& Pelphrey, 2008).

In several studies, teacher's ability to recognize, use and manage child's emotions has been considered in relation to teacher's ability to provide a psychologically safe environment (Morris, Denham, Basset, \& Curby, 2013), and it has been argued that teachers' responsiveness is an indicator of the quality of childcare, which is related to the teacher's ability to use supportive strategies in regulating children's emotions (Thomason \& La Paro, 2013; Buettner, Jeon, Hur, Rachel, \& Garcia, 2016).

Researchers have also identified factors that affect a preschool teacher's ability to react appropriately to children's negative emotions and complicated mutual relationships, such as depression (Jeon et al., 2014), stress (Zinsser et al., 2013), emotional exhaustion, as well as the knowledge and application of stress management strategies in solving various pedagogical situations in teacher education (Lang et al., 2017; Jeon, Hur, \& Buettner, 2016), etc.

The aforementioned emotional responsiveness studies were mostly focused on issues concerning the management of children's behavior, with less emphasis on teacher training and their social and emotional health strategies (Lang, Jeon, Sproat, Brothers, \& Buettner, 2020). At present, we can see that the amount of research aimed at the advancement of teachers' social and emotional skills is increasing, including the aspect of teacher's responsiveness and the acquisition of stress management strategies in preschool teacher education. (Poulou, Bassett, \& Denham, 2018; Jennings, Jeon, \& Roberts, 2020; Jeon \& Ardeleanu, 2020).

In connection with our study, it is important that several authors (Jeon et al., 2016) have adapted the methodology to study the responsiveness of preschool teachers.

However, the opinions of pre-service teachers working at the preschool educational institutions on teacher's responsiveness have not been sufficiently 
Jurgena et al., 2021. Comparative Study on the Understanding of Responsiveness in Pre-Service Preschool Teachers in the Covid-19 Emergency Situation (2018-2020)

studied so far, and we continue to study this issue (Jurgena, Cēdere, \& Keviša, 2020).

It is important to study the opinions of students working at the preschool educational institutions to identify the attitude of prospective preschool teachers to the role of teacher's responsiveness in pedagogical activity.

\section{Methodology}

The study was conducted in two phases - in 2018 and in 2020, when the study process of pre-service teachers was organized remotely.

The participants of the study were 600 students, pre-service preschool teachers, at the University of Latvia; 247 students participated in the study in the year 2018 (Group A) and 353 students - in 2020 (Group B). Most of the participants (87\%) were $1^{\text {st }}$ year students, but the rest were $2^{\text {nd }}$ year students. All the respondents were women.

In group $\mathrm{A}$, the average age of the participants was 28.0 years, but in group $\mathrm{B}-31.8$ years. All the respondents were part-time students.

There was used a questionnaire for the study of the responsiveness of preschool teachers elaborated by L. Jeon, E. Hur, and C. Buettner (Jeon et al., 2016). The questionnaire includes five different situations causing children's negative emotions with potential responses according to a 7-point scale (1 - very unlikely, 7 - very likely). Our research methodology has been tested (Jurgena et al., 2020).

The reliability (inter-item consistency) of the questionnaire according to Cronbach's alpha coefficient was .84.

The Mann-Whitney U test was used to compare two independent groups, and the Kruskal-Wallis Test - to compare several independent groups. The obtained data were processed with the SPSS program.

\section{Results and Discussion}

When conducting a comparative data analysis, several significant differences were identified between two phases of the study. The results of the first study were analyzed and published (Jurgena et al., 2020). The Mann-Whitney U test was performed to compare the responses of group A and group B participants. Table 1 shows the summary of teachers' action strategies with the most significant differences between the answers of students in group A and group B. 
SOCIETY. INTEGRATION. EDUCATION

Proceedings of the International Scientific Conference. Volume I, May $28^{\text {th }}-29^{\text {th }}$, 2021. 207-215

Table 1 Statistically Significant Differences between the Answers of Group A and Group B Respondents

\begin{tabular}{|c|c|c|c|c|}
\hline \multirow{2}{*}{ Items } & \multicolumn{2}{|c|}{$M$} & \multirow{2}{*}{$\begin{array}{c}\text { Mann- } \\
\text { Whitney } \\
U\end{array}$} & \multirow[b]{2}{*}{$p$} \\
\hline & $\begin{array}{l}\text { Group A } \\
(\mathrm{n}=247)\end{array}$ & $\begin{array}{l}\text { Group B } \\
(\mathrm{n}=353)\end{array}$ & & \\
\hline $\begin{array}{l}\text { 1d Encourage the child to express his/her } \\
\text { feelings of anger and frustration }\end{array}$ & 2.98 & 3.44 & 38380.0 & .011 \\
\hline $\begin{array}{l}\text { 1e Comfort the child and try to make him/her } \\
\text { feel better }\end{array}$ & 6.17 & 6.54 & 35506.5 & .000 \\
\hline 2c Help the child figure out how to fix the toy & 6.30 & 6.51 & 38082.0 & .002 \\
\hline 2d Tell the child it's OK to cry & 4.39 & 4.97 & 35564.0 & .000 \\
\hline $\begin{array}{l}\text { 3a Comfort the child and try to make him/her } \\
\text { feel better }\end{array}$ & 6.36 & 6.61 & 38169.0 & .002 \\
\hline $\begin{array}{l}\text { 3d Encourage the child to talk about his/her } \\
\text { feelings }\end{array}$ & 5.44 & 5.95 & 36099.5 & .000 \\
\hline $\begin{array}{l}\text { 4b Tell the child it's OK to cry if he/she feels } \\
\text { bad }\end{array}$ & 3.63 & 4.27 & 35469.0 & .000 \\
\hline $\begin{array}{l}\text { 4c Suggest an activity that would attract his/her } \\
\text { attention }\end{array}$ & 6.31 & 6.54 & 37581.0 & .001 \\
\hline 5b Tell the child that it is OK to feel nervous & 5.17 & 5.45 & 38769.5 & .018 \\
\hline
\end{tabular}

According to the mean values $M$ of students' answers (Table 1), the Covid19 emergency situation has increased the self-efficacy of prospective teachers and the level of confidence in their ability to execute certain actions or to achieve certain results, which corresponds to the opinion expressed in theory (Bandura, 1997). The students believe that they could help a child to solve his or her problems because their personal experience has also been related to dealing with stressful emotional situations.

Self-efficacy is known to be developed through reflection on one's own experiences (including the negative ones). At the time when it is necessary to adapt to the changing conditions of the labor market, people need to be flexible, and the importance of self-management is becoming more important in their career (Alhaddad, 2014). The students involved in the study combine work in preschool educational institutions with studies at the university because preschool educational institutions were not closed in Latvia during the pandemic.

Four age groups were created to identify whether students' opinions were related to their age: a) 17-20 years, b) 21-30 years, c) 31-40 years, d) 41 year and older. Using the Kruskal-Wallis test, it was found that in 2018 (Group A) there were no sharp differences between the opinions of students of different ages, while in the Covid-19 situation the differences in many items are statistically significant (Table 2). It can be concluded that the Covid-19 emergency situation has had an impact on students of all ages, and, in these conditions, there are more pronounced differences between the students of certain age groups (2c, 3a, 4d). 
Jurgena et al., 2021. Comparative Study on the Understanding of Responsiveness in Pre-Service Preschool Teachers in the Covid-19 Emergency Situation (2018-2020)

Table 2 Understanding of Responsiveness in Group A and Group B: Comparison by Age Groups

\begin{tabular}{|c|c|c|c|c|c|c|}
\hline \multirow{2}{*}{ Items } & \multicolumn{3}{|c|}{ Group A } & \multicolumn{3}{c|}{ Group B } \\
\cline { 2 - 7 } & $\chi^{2}$ & $d f$ & $p$ & $\chi^{2}$ & $d f$ & $p$ \\
\hline 1b & 7.98 & 3 & .047 & 9.80 & 3 & .020 \\
\hline 1c & 3.83 & 3 & .281 & 5.16 & 3 & .161 \\
\hline 1e & 4.19 & 3 & .242 & 8.50 & 3 & .037 \\
\hline 2a & 5.74 & 3 & .125 & 4.56 & 3 & .207 \\
\hline 2c & 3.03 & 3 & .387 & 11.06 & 3 & .011 \\
\hline 3a & .47 & 3 & .925 & 11.03 & 3 & .012 \\
\hline 3e & 6.14 & 3 & .105 & 2.63 & 3 & .452 \\
\hline $4 \mathrm{c}$ & 6.12 & 3 & .106 & 4.80 & 3 & .187 \\
\hline 4d & 8.63 & 3 & .035 & 17.13 & 3 & .001 \\
\hline 5a & 4.66 & 3 & .198 & 8.84 & 3 & .031 \\
\hline 5c & 6.66 & 3 & .084 & 9.43 & 3 & .024 \\
\hline
\end{tabular}

Analyzing the distribution of group A and group B answers in each age group separately, it was found that the Covid-19 emergency has had the strongest impact on the students in the age group of 21-30 years. Two highly valued forms of responsiveness stand out in this group of respondents - encouraging the child to talk about their feelings and encouraging constructive action (Fig. 1 and Fig. 2).

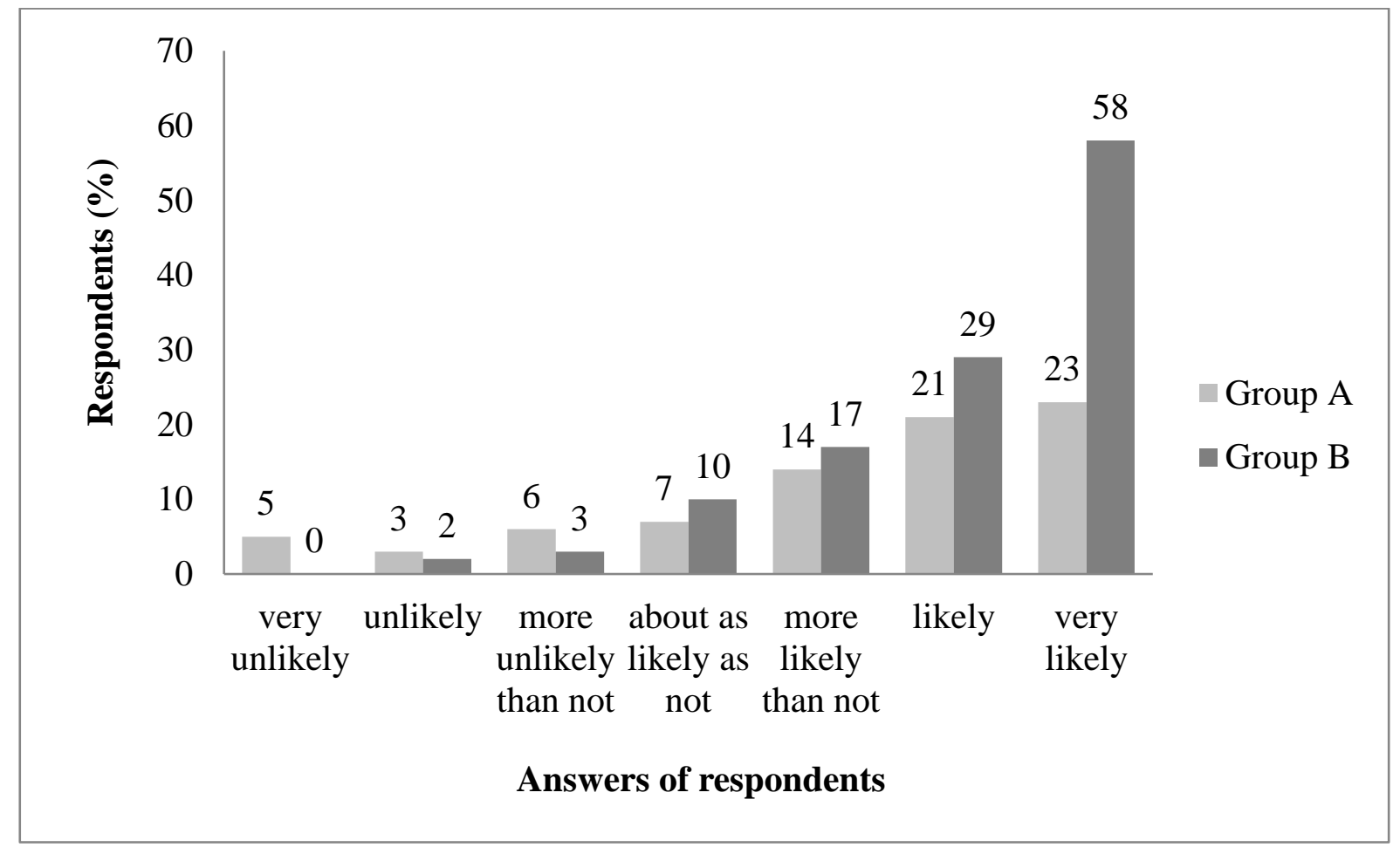

Figure 1 Encouraging the Child to Talk about Their Problem 


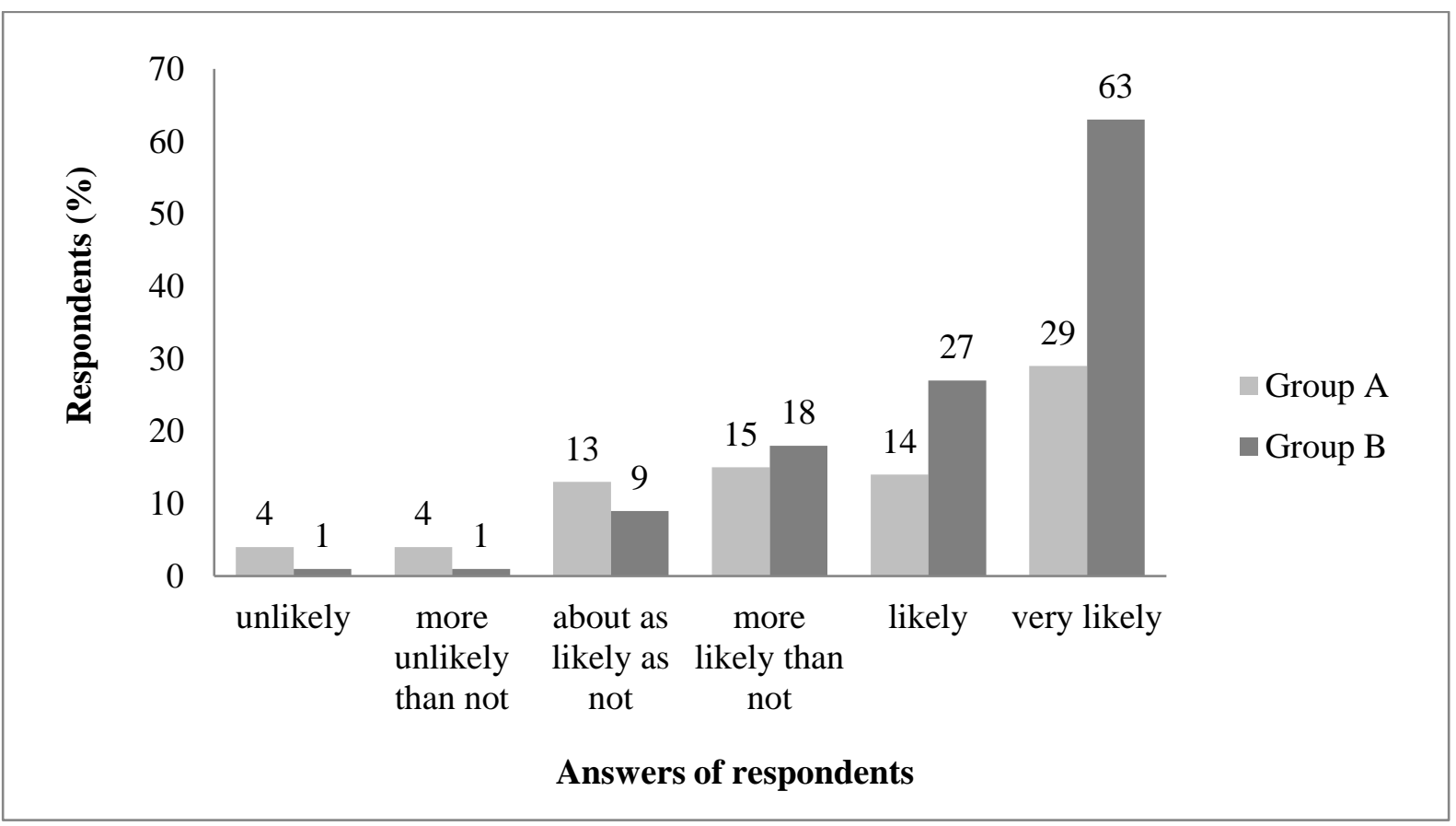

Figure 2 Helping the Child to Solve the Feelings and Act Constructively

Both examples (Fig.1 and Fig.2) show that group B students, compared to group A, express their understanding of the need to respond to child's negative emotions and difficult situations more convincingly. Most of the group B students are more convinced of the need to help the child act more constructively and resolve the problem.

The results of the study show that the Covid-19 pandemic has had certain impact on students' understanding and attitude to learning, but the relatively short research period does not allow us to draw conclusions on its long-term impact.

\section{Conclusions}

The results of the study conducted in 2020 show that, overall, the Covid-19 emergency has increased the responsibility of prospective preschool teachers and their willingness to undertake responsibility and leadership in regulating children's emotions. It appears that students have become more pragmatic and purposeful, and their understanding of the importance of responsiveness in the work of a teacher is better than before the pandemic.

\section{References}

Alhaddad, M. (2014). Career self-management in ascription culture. (Doctoral dissertation Brunel school of Business and Management, Brund University). Retrieved from http://bura.brunel.ac.uk/handle/2438/8746 
Jurgena et al., 2021. Comparative Study on the Understanding of Responsiveness in Pre-Service

Preschool Teachers in the Covid-19 Emergency Situation (2018-2020)

Allen, J., Rowan, L., Singh, P. (2020). Teaching and teacher education in the time of Covid-19. Asia -Pacific Journal of Teacher Education, 48(3), 233-236.

Bandura, A. (1997). Self-efficacy. The Exercise of Control. New York: W.H. Freeman and Company.

Buettner, C. K., Jeon, L., Hur, E., Rachel, E., \& Garcia, C. (2016.) Teachers' Social-Emotional Capacity: Factors Associated with Teachers' Responsiveness and Professional Commitment. Early Education and Development, 27(7), 1018-1039. https://doi.org/10.1080/10409289.2016.1168227

Cabinet of Ministers of the Republic of Latvia. (2020). Regulation No. 655. Regarding Declaration of the Emergency Situation. Latvijas Véstnesis, 216A, 06.11.2020.Retrieved from https://www.vestnesis.lv/ta/id/318517

Denham, S. A., Baset, H. H., \& Zinsser, K. (2012). Early Childhood Teachers as Socializers of Young Children's Emotional Competence. Early Childhood Education Journal, 40(3), 137-143.

Donitsa-Schmidt, L., Smadar, D., \& Ramot, R. (2020). Opportunities and Challenges: teacher education in Israel in the Covid-19 pandemic. Journal of Education for Teaching, 46(4), 586-595. https://doi.org/10.1080/02607476.2020.1799708

Fabes, R. A., Poulin, R. E., Eisenberg, N., \& Madden-Derdich, D. A. (2002). The coping with Children's Negative Emotions Scale (CCNS): Psychometric properties and relations with children's emotional competence. Marriage \& Family Review, 34(3-4), 285-310. Retrieved from https://psycnet.apa.org/doi/10.1300/J002v34n03_05

Ferreira, M., Martinsone, B., Talič, S. (2020). Promoting Sustainable Social Emotional Learning at School through Relationship Centred Learning Environment. Teaching Methods and Formative Assessment. Journal of Teacher Education for Sustainability, 22(1), 21-36.

Hadar, L. L., Ergas, O., Alpert, B, \& Ariav, T. (2020). Rethinking Teacher Education in a VUCA world: Student teachers' social-emotional competencies during the Covid-19 crisis. European Journal of Teacher Education, 43(4), 573-586. https://doi.org/10.1080/02619768.2020.1807513

Harvey, S. T., Evans, I. M., Hill, R.V. J., Henricksen, A., \& Bimler, D. (2016). Warming the emotional climate of the classroom: Can teachers' social-emotional skills change? The International Journal of Emotional Education, 8(2), 70-87.

Jennings, P. A., Jeon, L., \& Roberts, A. M. (2020). Introduction to the Special Issue on Early Care and Education Professionals' Social and Emotional Well-Being. Early Education and Development, 31(7), 933- 939. https://doi.org/10.1080/10409289.2020.1809895

Jeon, L., \& Ardeleanu, K. (2020). Work Climate in Early Care, and Education and Teachers' Stress: Indirect Associations through Emotion Regulation. Early Education and Development, 31(7), 1031-1051. https://doi.org/10.1080/10409289.2020.1776809

Jeon, L., Buettner, C. K., \& Snyder, A. R. (2014). Pathways from teacher depression and childcare quality to child behavioral problems. Journal of Consulting and Clinical Psychology, 82(2), 225-235. https://psycnet.apa.org/doi/10.1037/a0035720

Jeon, L., Hur, E., \& Buettner, C. K. (2016). Child-care chaos and teacher’s responsiveness: The indirect associations through teacher's emotion regulation and coping. Journal of School Psychology, Volume 59, 83-96.

Jurgena, I., Cēdere, D., \& Keviša, I. (2020). The pedagogical evaluation of responsiveness of pre-service teachers. Society. Integration. Education. Proceedings of the International Scientific Conference, Vol.1 Higher Education, May 22nd-23rd, Rezekne: Rezekne Academy of Technologies, 276 -287. 
Lang, S. N., Jeon, L., Sproat, E. B., Brothers, B. E., \& Buettner, C. K. (2020). Social and Emotional Learning for Teachers (Self-T): A Short-term Online Intervention to Increase Early Childhood Educators' Resilience. Early Education and Development, 31(7), 11121132. https://doi.org/10.1080/10409289.2020.1749820

Lang, S., N., Mouzourou, C., Jeon, L., Buettner C., \& Hur, E. (2017). Preschool Teachers' Professional Training, Observational Feedback, Child-Centred Beliefs and Motivation: Direct and Indirect Associations with Social and Emotional Responsiveness. Child and Youth Care Forum, 46(1), 69-90.

Morris, C. A. S., Denham, S. A., Bassett, H. H., \& Curby, T. W. (2013). Relations among teachers' emotion, socialization, beliefs and practices and preschoolers' emotional competence. Early Education \& Development, 24(7), 979-999. doi: $10.1080 / 10409289.2013 .825186$

OECD. (2019). OECD Skills Strategy Latvia: Assessment and Recommendations. https://doi.org/10.1787/74fe3bf8-en

Poulou, M., S., Basett, H. H., \& Denham S. A., (2018). Teachers' Perceptions of Emotional Intelligence and Social-Emotional Learning: Students' Emotional and Behavioral Difficulties in U.S. and Greek Preschool Classrooms. Journal of Research in Childhood Education, 32(3), 363-377.

Sangiter, A., Stoner, G., \& Flood, B. (2020). Insights into accounting education in a Covid-19 World. Accounting Education, 29(5), 431-562. https://doi.org/10.1080/ 09639284.2020.1808487

Thomason, A. C., \& La Paro, K. M. (2013). Teachers' commitment to the field and teacherchild interactions in center based childcare for toddlers and three-year-olds. Early Childhood Education Journal, 41(3), 227-234. DOI: 10.1007/s10643-012-0539-4

UNESCO. (2020). UNESCO COVID-19 education response: how many students are at risk of not returning to school? Advocacy paper. UNESDOC Digital Library.

UNICEF. (2020). UNICEF and Microsoft launch global learning platform to help address Covid-19 education crisis.

La Velle, L., Newman, S., Montgomery, C., \& Hyatt, D. (2020). Initial teacher education in England and the Covid-19: Challenges and opportunities. Journal of Education for Teaching, 46(4), 596-608. https://doi.org/10.1080/02607476.2020.1803051

Zinsser, K. M., Bailey, C. S., Curby, T. N., Denham, S. A., \& Bassett, H. H. (2013). Exploring the predictable classroom: preschool teacher stress, emotional supportiveness and students' social emotional behavior in private and head start classrooms. NHSA Dialog, 16(2), 90-108. 